\title{
A Pluralist Approach to the Law of International Sales
}

\section{J Coetzee*}

\section{P.E.R}

Pioneer in peer-reviewed, open access online law publications.

Author

Juana Coetzee

Affiliation

Stellenbosch University, South Africa

Email

jcoet@sun.ac.za

Date published

13 March 2017

Editor Prof KD Beiter

How to cite this article

Coetzee $\mathrm{J}$ "A Pluralist Approach to the Law of International Sales" PER / PELJ 2017(20) - DOI http://dx.doi.org/10.17159/17273781/2017/v20i0a1355

\section{Copyright}

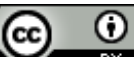

DOI

http://dx.doi.org/10.17159/1727-

3781/2017/v20i0a1355

\begin{abstract}
International trade can support economic development and social upliftment. However, people are often discouraged from contracting internationally due to the existence of differences in legal systems which act as a non-tariff barrier to trade. This article focuses on the private law framework regulating international contracts of sale. During the twentieth century the problem of diverse laws was primarily addressed by global uniform law such as the United Nations Convention on Contracts for the International Sale of Goods (CISG). However, uniform law is rarely complete and has to be supplemented by national law, trade usage or party agreement. Because there are gaps in the CISG the Swiss government has made a proposal for a new global contract law. But is this a feasible solution to the fragmentary state of international trade law? In Europe, signs of resistance are setting in against further harmonisation. The Proposal for a Common European Sales Law (CESL) was recently withdrawn, and now Britain has voted to leave the European Union. Rumour has it that more countries might follow. The current private law framework for international sales contracts consists of a hybrid system where international, national, state and non-state law function side by side. This article submits that universalism is not per se the most efficient approach to the regulation of international sales law and that economic forces require a more varied approach for businessto-business transactions. The biggest challenge, however, would be to manage global legal pluralism. It is concluded that contractual parties, the courts and arbitral tribunals can effectively manage pluralism on a case-by-case basis.
\end{abstract}

\section{Keywords}

Global legal pluralism; unified law; legal harmonisation; international sales; international contracts. 


\section{Introduction}

From a private law perspective, one of the major challenges faced by an international contract of sale is the diversity of legal systems that might potentially apply to it. In the modern day commercial context, this problem is exacerbated by global supply chains and contractual networks which operate across a number of countries.

In the twentieth century, the focus was placed on a universalist framework which addresses the uncertainties and transaction costs connected to the problem of the existence of diverse legal systems by means of globalised or uniform law. ${ }^{1}$ As early as before the Second World War the German scholar Ernst Rabel suggested the possibility of a uniform sales law to the Institute for the Harmonisation of Private Law (UNIDROIT). ${ }^{2}$ In the early 1930s UNIDROIT initiated a project to prepare a law unifying the substantive rules governing international sales contracts under the auspices of the League of Nations. Led by Rabel, a commission of European scholars drafted a preliminary report which was presented in 1935. The Second World War interrupted the work but it was resumed in 1951 with a conference at The Hague. In 1964 the drafting process for a unified sales law ended with a diplomatic conference at The Hague where two conventions unifying the law of the international sale of goods were adopted, namely the Uniform Law on the International Sale of Goods (ULIS) and the Uniform Law on the Formation of Contracts for the International Sale of Goods (ULF). The Hague Conventions came into force in $1972 .{ }^{3}$ However, these conventions never really found support outside Western Europe and they still do not enjoy wide recognition as instruments of international harmonisation. ${ }^{4}$ Shortly after the United Nations Commission for International Trade Law was established in 1968, the organisation embarked on drafting a new unified sales law. In 1980, after a decade of negotiations, the final draft of the United Nations Convention on Contracts for the International Sale of Goods (CISG or the Convention) was approved by the United Nations General Assembly, and

\footnotetext{
Juana Coetzee. BA LLB LLM LLD (Stellenbosch University). Associate Professor, Department of Mercantile Law, University of Stellenbosch. Email: jcoet@sun.ac.za.

1 Caliess and Buchmann 2016 https://papers.ssrn.com/sol3/papers.cfm? abstract_id=2717467 2 .

Rabel 1935 RabelsZ1.

Sono 1984 Int'l Law 12-13; Winship 1988 Cornell Int'I LJ 489-490.

They were adopted by only nine countries, namely Belgium, Gambia, Germany, Israel, Italy, Luxembourg, the Netherlands, San Marino and the United Kingdom. Belgium, Germany, Italy, Luxembourg and the Netherlands subsequently denounced their ratifications when they ratified the CISG.
} 
it finally came into operation on 1 January 1988. Today the CISG is supported by a number of conventions dealing with aspects related to the international sale of goods, ${ }^{5}$ such as the 1974 United Nations Convention on the Limitation Period in the International Sale of Goods, ${ }^{6}$ the 1983 Geneva Convention on Agency in the International Sale of Goods, ${ }^{7}$ the 2005 United Nations Convention on the Use of Electronic Communications in International Contracts ${ }^{8}$ and the 1983 Uniform Rules on Contract Clauses for an Agreed Sum Due upon Failure of Performance. ${ }^{9}$ As of May 2016, 85 countries have ratified or acceded to the Convention. ${ }^{10}$ As a result it is hailed as one of the most successful examples of private law unification to date. ${ }^{11}$

Whether the CISG succeeded in developing international trade as envisaged by its preamble is, however, a different question altogether. Although most of the countries participating in international trade are Contracting States to the Convention, there are no statistics to prove that most of international sales contracts concluded worldwide are in actual fact governed by the CISG. ${ }^{12}$ Moreover, the high number of ratifications does not mean that the Convention unifies international sales law effectively, or that it provides contractual parties with a useful or efficient regulatory framework.

For one, the Convention is based on the principle of party autonomy. That means that contractual parties are free to exclude the CISG as the governing law of their contract, which is often done in business-tobusiness transactions. ${ }^{13}$ Furthermore, as Contracting States are allowed to make reservations at the time of ratification or accession, parts of the Convention can be excluded. This creates uncertainty amongst

\footnotetext{
See in general, Castellani "CISG in Context" 683-693.

This convention was subsequently modified by the 1980 Protocol. Currently 30 countries are party to the unamended Convention and 23 of those also to the amended Convention.

7 As this Convention has not come into operation yet, it can apply only as soft law.

8 This Convention came into operation in 2013 and to date has only seven Contracting States.

9 UN Doc A/CN 9/243, annex I.

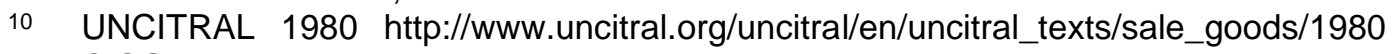
CISG_status_chronological.html.

11 Smits "Problems of Uniform Laws" 605; Zhou "CISG and English Law" 669; Schwenzer 2016 Unif L Rev 64.

12 Schroeter "Empirical Evidence" 649.

13 Smits "Problems of Uniform Laws" 609; Zhou "CISG and English Law" 670, 676; Schroeter "Empirical Evidence" 649.
} 
contractual parties and refutes the notion that there is a uniform sales law aimed at the reduction of legal uncertainty. ${ }^{14}$

The Convention's limited scope and its piecemeal nature create further uncertainty. Where the parties have not specifically provided for matters excluded from the Convention's ambit, they are addressed by national law. ${ }^{15}$ This means that the very rules of private international law which the supporters of uniform law want to avoid are still being applied. ${ }^{16}$ Moreover, due to its nature as a compromise, many of the Convention's provisions contain so-called "internal gaps". ${ }^{17}$ These are to be filled through a process of autonomous interpretation. The same applies to its neutral terminology, which is often vague and ambiguous. ${ }^{18}$ In solving interpretational disputes, national courts and arbitral tribunals have to take the Convention's "international character and the need to promote uniformity in its application and the observance of good faith in international trade" into consideration. ${ }^{19}$ This is merely a directive and one that is couched in language which in itself is vague and open for interpretation. Moreover, in the absence of a formal precedent system, there is no formal guarantee that the provisions of the Convention will be interpreted uniformly, as it depends largely on the good faith of judges and arbitrators whether they will keep to the drafters' guidelines. ${ }^{20}$ Article $7(2)$ of the CISG prescribes that, when internal gaps are to be filled, the courts and tribunals are to make use of the general principles on which the Convention is based. However, the CISG does not state or list what these principles are and, consequently, they have to be deduced from the other provisions of the Convention through a process of analogy. ${ }^{21}$ Where no general principles are to be found, the judge may venture outside the four corners of the CISG and settle the matter in conformity with the applicable law. ${ }^{22}$ It is, therefore, clear that the CISG does not unify the law of international sales in an exhaustive manner but instead operates in a supplementary and symbiotic relationship with national law, trade usage, party autonomy and other international instruments of harmonisation.

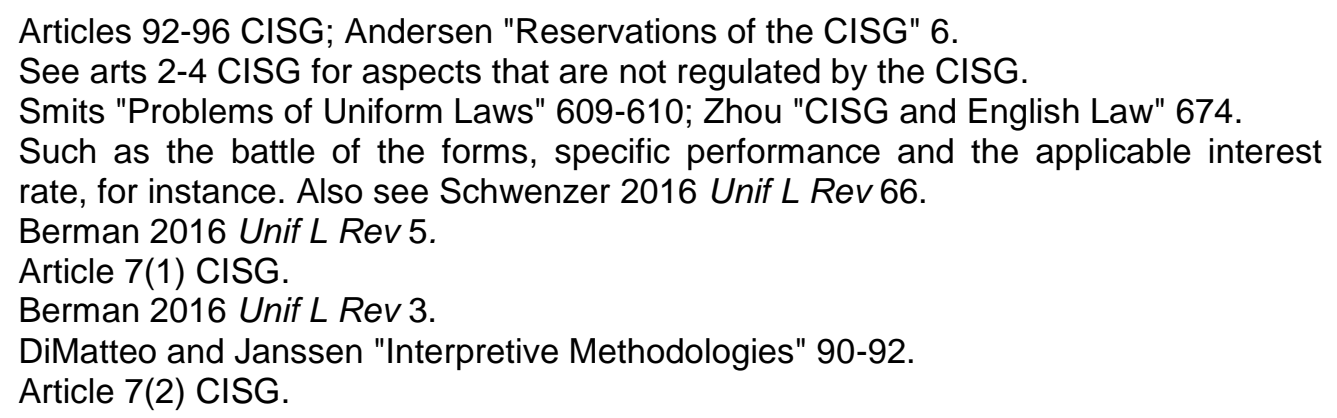


Against this background, one has to ask whether a unified sales law is feasible, or conducive to international trade. A rise in the creation of regional and other instruments of harmonisation indicates that the CISG is not effective in regulating all matters of the substantive law applicable to international sales and that it fails to address specific regional needs. The UNIDROIT Principles of International Commercial Contracts (PICC), the Draft Principles of European Contract Law (PECL), the Draft Common Frame of Reference (DCFR), a proposal for a Common European Sales Law (CESL), the Uniform Act on General Commercial Law drafted by the Organisation for the Harmonisation of Business Laws in Africa (OHADA), the Principles of Asian Contract Law (PACL), and the Principles of Latin American Contract Law (PLDC) have been noted as attempts to regulate and supplement the CISG's shortcomings. ${ }^{23}$ Apart from the draft CESL and the OHADA laws, these are mostly soft law instruments that are not automatically binding on the parties.

In 2012, at the $45^{\text {th }}$ session of the United Nations Commission on International Trade Law (UNCITRAL), the Swiss government introduced a proposal which suggested that the limited scope and piecemeal nature of the CISG necessitate an assessment of the Convention to determine whether it fulfils the present needs of international business and will be able to do so in future. ${ }^{24}$ The Commission was urged to discuss the desirability and feasibility of future work on a unified international contract law. The Swiss Proposal is based on two premises, namely that differences in laws act as an obstacle to international trade, and that legal systems that function as a choice of law are often ill suited for the regulation of international contracts. It was further submitted that as an opt-in soft law instrument the UNIDROIT Principles of International Commercial Contracts (PICC) cannot fill the gaps left by the CISG. The Proposal, furthermore, assumed that international contracts are best regulated through a single global law. ${ }^{25}$

The Swiss Proposal rehashed the old debate on the pros and cons of private law unification. In essence, scholars evaluated the proposal on two bases, namely whether there is a need for further work in this area, and whether the flaws in the CISG will be adequately addressed by a new global contract law. Critics concluded that the Proposal failed to articulate

\footnotetext{
23 Schwenzer 2016 Unif L Rev 68-70.

24 Possible Future Work in the Area of International Contract Law: Proposal by Switzerland on Possible Future Work by UNCITRAL in the Area of International Contract Law UN Doc A/CN 9/758 (2012).

25 Schwenzer 2016 Unif L Rev 74.
} 
a need for and the scope of any further unification clearly. They also warned against the shortcomings of a convention as a means of harmonising differences in laws, the potential for further fragmentation if another law were to be created, and the redundancy of a new global framework law while the PICC still existed. ${ }^{26}$

The point of departure of this article is to agree with these points of criticism but to add another dimension to the debate. This article argues that it is impossible to unify international contract law by means of a single instrument, and that all uniform law would, therefore, contain elements of pluralism. Moreover, recent developments such as Britain's vote to leave the European Union (EU) call for a reconsideration of how one thinks about law and transnational or unified law in particular. Earlier, a Proposal for a Common European Sales Law (CESL) was also withdrawn. Although these events might signal a move towards increased nationalism, the discourse should not merely be informed by the traditional debate on universalism (global law) versus territorialism (national law) as neither of these theories can exist in isolation. The central thesis of this article is that, instead of eradicating the hybrid character of international commercial law, it should be recognised that international sales law already functions within a pluralist framework and that the focus should rather be shifted towards how to manage global legal pluralism effectively.

As the current framework of international sales law seems to favour universalism, at least in theory, the article commences with a historic overview of uniform law. That will be followed by a discussion of the practical realities of international sales law regulation - especially in business-to-business relationships. This discussion takes place against the backdrop of the criticism against the Swiss Proposal for a Global Contract Law, and increasing signs of reluctance to engage in further harmonisation efforts in Europe. Emphasis will be placed on the problems and myths connected to uniform law and the fact that multiple role-players are shaping the face of international sales law. The third part will focus on the features of an effective regulatory framework, and on who will determine what those features are. Methods of managing global legal pluralism will also be discussed, and specific reference will be made to the inherently pluralist nature of the CISG.

26 For a discussion on the shortcomings of the Proposal, see Dennis 2014 Unif $L$ Rev; Gabriel 2013 Vill L Rev. 


\section{The current framework of international sales law}

\subsection{General background}

Scholars regard differences in legal systems as being among the major non-tariff barriers to international trade. ${ }^{27}$ Proponents of uniform law base their arguments on a reduction in transaction costs brought about by having a single neutral law governing the contract. ${ }^{28}$ Uniform law dispenses with the need to determine the applicable law and to learn it. ${ }^{29}$

The concept of a global commercial law is nothing new. It can be traced back to medieval times and an autonomous legal system applicable to international trade based on international customs and usages, the socalled ancient lex mercatoria. ${ }^{30}$ However, the notion that there was an ancient world law regulating commercial transactions is quite controversial as there are differing opinions on whether or not such an autonomous law ever existed, and if so, what its scope would have been. ${ }^{31}$ What is clear, though, is that the rise of nationalism and territorial sovereignism in the eighteenth and nineteenth centuries caused contract law to develop along geographical lines, resulting in contracts being regulated by stateauthorised legal systems. Naturally, many of these systems have common features that bind them together on the basis of their historical origin into what is sometimes referred to as legal families.

In the twentieth century globalisation spurred an increase in international business transactions. With it, uncertainties created by the differences in legal systems led to calls for the unification of law. A solution was sought in the formulation of a global or world law where international governing bodies such as UNCITRAL would play a major role. ${ }^{32}$ As a result, the CISG was introduced to regulate the substantive law applicable to international sales contracts. Today, the universalist framework of international sales law consists of a myriad of rules functioning on different levels - global, regional and national. In addition to state law, international agencies and organisations with or without state representation, business

27 Schwenzer 2013 Vill L Rev 723, 725-727; Caliess and Buchmann 2016 https://papers.ssrn.com/sol3/papers.cfm?abstract_id=2717467 4; Wagner "Costs of legal uncertainty" 53.

28 Wagner "Transaction costs" 39-40; Wagner "Costs of Legal Certainty" 53-57.

29 Zhou "CISG and English Law" 674; Schwenzer 2016 Unif L Rev 60-64.

30 Berman 2016 Unif L Rev 2.

31 See, for example, Fassberg 2004 Chi J Int'I L; Kadens 2012 Texas LR.

32 Caliess and Buchmann 2016 https://papers.ssrn.com/sol3/papers.cfm? abstract_id=2717467 2. 
associations, and commercial parties all participate in what some would call the creation of a new lex mercatoria. ${ }^{33}$ These rules operate in the form of hard law (for example, international conventions or national laws), or in the form of soft law (such as general principles of law, model laws, standard form contracts, trade usages and customs). ${ }^{34}$ As soft law rules are not automatically binding, their existence is dependent on party agreement. Although they can displace the default law of the contract in toto, they function mainly in conjunction with or as supplementary to hard law. It is therefore clear that in practice the ideal of a single "world law" has not yet been achieved.

The Swiss Proposal for a global contract law builds on the foundations of the traditional lex mercatoria. At the same time, it resembles the notion of a consolidated commercial code. The idea of a global commercial code was first launched in 1970 when the UNIDROIT Secretariat submitted a note to the newly established UNCITRAL. The code was to address all aspects of international commercial law in a single instrument, ${ }^{35}$ and to that extent it has a broader scope than the Swiss Proposal. What was suggested was a code that consists of two parts, one dealing with the law of obligations in general and another with specific types of commercial transactions. The project was initially greeted with scepticism and became feasible only in later years when UNIDROIT initiated its project on the General Principles of International Commercial Contracts. ${ }^{36}$ Originally, the Principles were to function as the basis of a uniform code of international commercial law. ${ }^{37}$ Scholars reintroduced the call for a global commercial law at regular intervals. In the 1980s, Schmitthoff joined in by propagating a world code of international trade law that would consolidate and systemise a number of existing and future uniform laws in the field of international trade law. ${ }^{38}$ In 2000 the idea of a global commercial code was again revived by the then Secretary-General of UNCITRAL, Gerold

33 Caliess and Buchmann 2016 https://papers.ssrn.com/sol3/papers.cfm? abstract_id=2717467 1 .

34 These are not hard and fast categories as typical hard law can often operate on a soft-law level, for example where contractual parties agree to have their contract governed by a convention such as the CISG in circumstances where it would otherwise not automatically govern. Spagnolo "CISG as Soft Law" 154.

35 Note by the Secretariat of the International Institute for the Unification of Private Law (UNIDROIT): Progressive Codification of the Law of International Trade UN Doc A/CN 9/L.19 (1970).

36 Bonell 2000 Unif $L$ Rev 469.

37 Michaels 2014 Unif $L$ Rev 643, 645.

38 Schmitthoff "Law of International Trade" 230; Schmitthoff "Codification of the Law of International Trade" 249-251. 
Hermann. ${ }^{39}$ Scholars such as Lando and Bonell support the vision of a global commercial code. Keeping to Schmitthoff and Hermann's ideas, they do not envisage a comprehensive international code to replace all existing national laws but rather a body of rules relating to the most important kinds of commercial transactions. ${ }^{40}$ Some of these rules already exist in the form of international conventions or model laws, whereas others would have to be added. ${ }^{41}$ However, their vision is that the existing rules should not merely be transplanted into a new global code but that they should first be assimilated as regards terminology and content. ${ }^{42}$ Unlike Hermann, who focused on commercial rules only, they propose that the general principles of contract law as provided by the PICC should also form part of the global code. They differ, however, on the role of the PICC. Bonell believes that the general principles of contract should only supplement the global commercial code and that the code should therefore explicitly state that the PICC is to function as a supplementary non-binding instrument. ${ }^{43}$ Lando, on the other hand, advocates the incorporation of the PICC into the global code as binding rules of law. ${ }^{44}$

As is the case with the Swiss Proposal today, not everybody was convinced of the need for a global commercial code. The possibilities that a global code might bring to stimulate academic thinking and writing, promote cooperation between jurists on an international level, and even produce texts for the benefit and use of developing nations were recognised. What many people remained unconvinced of was the need for unified law in a hard-law format, mainly because of the inefficiency and disadvantages of conventions per se. ${ }^{45}$ It was argued that the principle of party autonomy enables parties to structure their contracts in such a way that there would not be a need for harmonised law, such as to provide for a single law of their choice, that all disputes are to be referred for arbitration, or to use tailor-made terms and standard-form contracts. ${ }^{46}$ Today these arguments are resurfacing not only in reaction to the Swiss

39 Herrmann "Law, International Commerce and the Formulating Agencies"; Hermann "Towards a Global Commercial Code".

$40 \quad$ Bonell 2000 Unif $L$ Rev 473.

41 They propose that some of the existing rules such as the CISG, various transport law conventions, the Leasing and Factoring Conventions, Incoterms, the ICC Uniform Commercial Practice for Documentary Credits (UCP) and the Model Laws on Electronic Commerce and Arbitration can be integrated into such a code.

42 Bonell 2000 Unif L Rev 473-474; Lando 2003 Unif L Rev 123, 133.

43 Bonell 2000 Unif L Rev 479-481; Bonell 2008 Am J Comp L 27-28.

44 Lando 2003 Unif L Rev 132.

45 Farnsworth 2003 Unif $L$ Rev 97, 103-106. Also see Dennis 2014 Unif $L$ Rev 122.

46 Farnsworth 1996 Can Bus LJ 52-53. 
Proposal but also in legal scholarship on the current state of international contract law.

\subsection{Criticism of universalism as a legal framework}

Despite the advantages of uniform law, there are also a number of myths associated with the notion of global law and universalism. In order to evaluate the efficiency of universalism as a legal framework, it is necessary to consider these aspects.

Scholars point out that there is a lack of empirical proof that businesses actually perceive diverse laws as a barrier to international trade. ${ }^{47}$ The main premise on which the supporters of global harmonisation base their arguments is a reduction in transaction costs. Since business people rarely concern themselves with the governing law of their contract, this largely remains a theoretical argument. ${ }^{48}$ In most instances they trade with partners with whom they have a longstanding relationship, and when a dispute arises they usually settle it without legal recourse. ${ }^{49}$ Differences in language, cultural habits and other types of law, such as tax and procedural law, are often of greater concern to contractual parties than differences in contract laws. ${ }^{50}$ When it comes to the law of contract, parties and their lawyers are generally more concerned that the law is able to address the needs and interests of the parties and their transaction than with whether it is a unified law. ${ }^{51}$

Furthermore, there is no empirical evidence to support the notion that uniform law provides greater legal certainty than diverse national laws, or that unified law enhances international trade. ${ }^{52}$ Uniform law rarely covers all aspects applicable to a particular transaction and it still has to be supplemented by national law, party agreement or other international instruments of harmonisation. The result is multiple layers of law

\footnotetext{
Dennis 2014 Unif L Rev 124-127.

Berman 2016 Unif L Rev 8-9.

Smits "Economic Arguments" 47.

50 Smits "Economic Arguments" 48; Smits "Problems of Uniform Laws" 606; Dennis 2014 Unif L Rev 42.

51 Smits "Problems of Uniform Laws" 607; Gabriel "Choice of Law" 225-228; Berman 2016 Unif L Rev 8. See also Current Trends in the Field of International Sale of Goods Law UN Doc A/CN 9/849 (2015) para 14; Moser "Choice of Law in Practice".

52 Smits "Problems of Uniform Laws" 607; Smits "Economic Arguments" 51-52. Also see, in general, Schroeter "Empirical Evidence"; Zhou "CISG and English Law"; Cuniberti 2014 Nw J Int'l L \& Bus.
} 
governing a single transaction. ${ }^{53}$ Moreover, unified law is not always efficient law, especially not if it is created through a process of compromise, as is usually the case with international conventions. Often uniform law exists only on paper, as true uniformity depends on uniform interpretation of its provisions by courts and arbitral tribunals. ${ }^{54}$ This has always been one of the main challenges in the implementation of the CISG. More than thirty-five years later, the case law on the CISG still shows signs of a so-called "homeward trend". ${ }^{55}$ Furthermore, the default and opt-out natures of uniform laws such as the CISG restrict the ideal of a world law. Behavioural patterns show that contractual parties still opt out of uniform law in favour of default national law (the so-called status quo law) with which they are more familiar. ${ }^{56}$

Although unified or harmonised law has its advantages, these benefits should not be seen in isolation but must be weighed against the benefits that diversity can bring. A reduction in transaction costs as a result of having greater legal certainty and predictability is one of the main benefits of unified and harmonised law. However, differences in laws provide the basis for comparative analysis that encourages and facilitates further development of the law. If all laws were the same, further development would be inhibited. ${ }^{57}$

General political and economic considerations should also be taken into account. The rise of transnational law took place in a specific era, namely after two World Wars and in the face of an emerging Cold War. This might have been an apt approach for its time; however, harmonisation projects are often perceived as elitist, undemocratic and an inroad into the sovereignty of the nation state..$^{58}$ Recently there have been signs of resistance to new unification efforts, especially in a hard law format. Attempts to revise article 2 of the American Uniform Commercial Code (UCC) and to formulate an opt-in common sales law for Europe both failed, which shows that efforts to formulate uniform law are rarely

53 Current Trends in the Field of International Sale of Goods Law UN Doc A/CN 9/849 (2015) para 43; Smits 2013 https://papers.ssrn.com/sol3/papers.cfm? abstract_id=2197468 5 .

54 Wagner "Transaction Costs" 43.

55 Schwenzer "Divergent Interpretations" 103-104.

56 Smits "Problems of Uniform Laws" 609-610; Smits "Economic Arguments" 50; Current Trends in the Field of International Sale of Goods Law UN Doc A/CN 9/849 (2015) para 13. Also see Schroeter "Empirical Evidence"; Cuniberti 2014 Nw J Int'l L \& Bus.

57 Wagner "Transaction Costs" 40; Wagner "Costs of Legal Certainty" 58.

58 Michaels 2016 German LJ 57-59. 
successful and often remain of only academic value. ${ }^{59}$ In the European context, especially, it seems that the harmonisation movement is losing its original momentum and that reluctance is setting in to engage in further legal harmonisation. ${ }^{60}$ Britain's decision to leave the European Union will certainly contribute to more questions on the feasibility of harmonisation and transnational law. ${ }^{61}$ The European legal system has become a "patchwork of overlapping and partly contradictory rules"62 which can give rise to challenges of accessibility and predictability. Moreover, it is said that the multilevel private law system in Europe operates within an ineffective political framework where the regional legislature cannot realise effective rules any longer, resulting in a regulatory void being left. It is predicted that globalisation and unification will remain important frameworks but that the void will increasingly be filled by national legislation, specialised courts, party autonomy and privately generated law. ${ }^{63}$ Although these remarks are made with specific reference to the European context, useful lessons can be drawn from it for global harmonisation.

Supporters of uniform law often emphasise the benefits of hard law, especially that of international conventions. One of the advantages is that conventions are formulated by state-represented organisations and that they become part of state law once ratified or incorporated into national law, which means that they are automatically enforceable. ${ }^{64}$ Because softlaw instruments are not tested in a political process where governments, industry and business organisations participate in the drafting process, concerns about their legitimacy can arise. ${ }^{65}$ Moreover, the political will of states may often be too weak to use a soft law instrument as a model for legislative review or to recognise it as a choice of law. ${ }^{66}$

Although many of the gaps in the CISG have already been covered by the PICC, the Swiss Proposal still sees the need for a new global contract code, because the PICC is a non-state soft-law instrument with an opt-in nature. ${ }^{67}$ On the other hand, scholars who are opposed to the Proposal

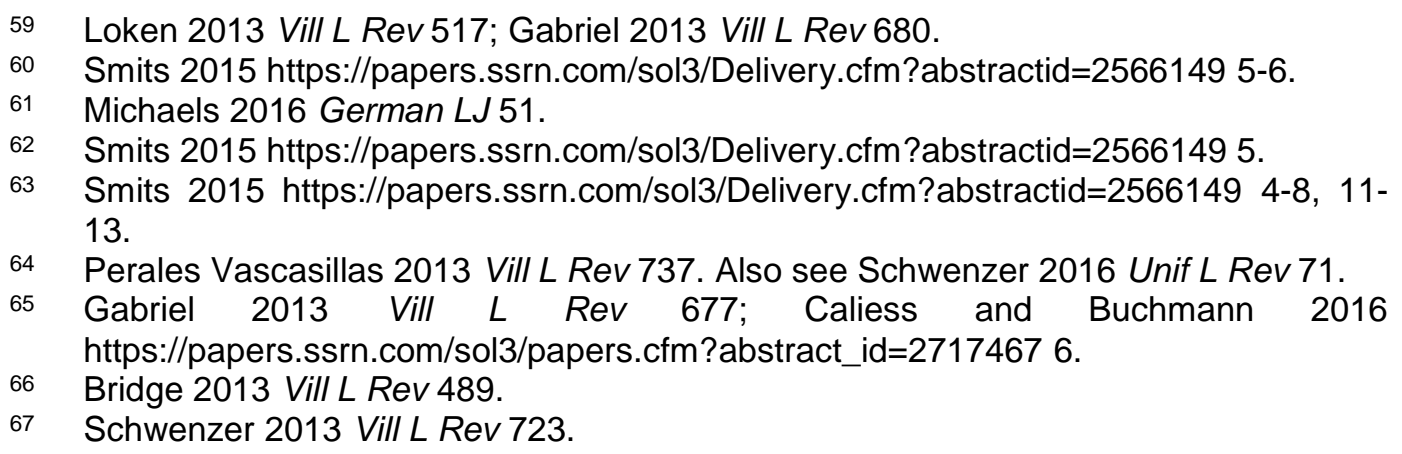


are of the view that soft law can provide a much more viable form of global uniformity. The UNCITRAL working method does not lend itself to the level of detail which is required to fill the gaps in the CISG. If a convention is used there will be a need to accommodate the specific legal traditions and national laws of a vast array of countries, which would make it difficult to reach agreement on the content of the rules. As UNIDROIT does not have any government representation it would be much easier to reach consensus on contentious issues. ${ }^{68}$ Moreover, a binding instrument in the form of a convention would not necessarily provide greater legal certainty as parties can still contract out of it. ${ }^{69}$ States, furthermore, often lack the necessary political will to ratify conventions, as is evident from the low ratification rate of the CISG in Africa and other developing countries.

What makes soft law instruments a better choice is that they can be developed, updated and amended without a formalised process, ${ }^{70}$ as against conventions, where the process is slow and expensive. ${ }^{71}$ Because conventions are politically driven, the best solution is rarely found and the final product is often a diplomatic compromise. ${ }^{72}$ As the shortcomings in the CISG are the result of compromises it is unlikely that the drafters of a new code would be able to reach consensus on the issues they failed to agree on in the $\mathrm{CISG},{ }^{73}$ especially where countries with different economic, ideological and legal backgrounds are involved. Furthermore, if a new convention were to be drafted it would only replicate the CISG, or worse, legal uncertainty would be increased by having inconsistent and duplicate conventions on the same subject-matter. ${ }^{74}$ It is also uncertain whether a new convention would be widely ratified within a reasonable time, and a new law may even affect further ratifications of the CISG. Similarly, if a new soft law instrument were to be formulated it would be redundant, amount to duplication, and be a waste of time and money as the PICC already covers most of the gaps in the CISG. ${ }^{75}$

68 Gabriel 2013 Vill L Rev 666, 673; Veneziano 2013 Vill L Rev 523-524.

69 Gabriel 2013 Vill L Rev 666, 671; Dennis 2014 Unif L Rev 144; Veneziano 2013 Vill L Rev 526-527.

70 Gabriel 2013 Vill L Rev 671; Bonell "Towards a Legislative Codification" 232.

71 Dennis 2014 Unif L Rev 138.

72 Gabriel 2013 Vill L Rev 670, 677; Dennis 2014 Unif L Rev 138-140; Gabriel 2013 Vill L Rev 672; Zhou "CISG and English Law" 676, 679, 681

73 Dennis 2014 Unif L Rev 140; Loken 2013 Vill L Rev 517; Gabriel 2013 Vill L Rev 665-666.

74 Gabriel 2013 Vill L Rev 679; Current Trends in the Field of International Sale of Goods Law UN Doc A/CN 9/849 (2015) para 43.

75 Gabriel 2013 Vill L Rev 663, 666-667; Veneziano 2013 Vill L Rev 527. 
In summary, it seems that there is no empirical evidence of a need to unify the substantive law applicable to international contracts beyond that which is already available. Neither is there any evidence that another uniform law would be viable, or at all successful. Universalism is a theoretical ideal that has scarcely come to fruition in practice, in that it fails to function as a stand-alone legal framework.

\subsection{Multiple norm-creating communities}

In the nineteenth century normative authority was traditionally hosted in the state. The latter part of the twentieth century, however, marked a shift to other norm-creating communities such as trade associations and business organisations, which operate as private rule-makers. Today the law is shaped by a variety of actors on different levels. This means that international contract law consists of a plurality of sources that include not only national and international legislators but also private regulators, trade customs and practices and the contractual parties themselves. ${ }^{76}$

The legal framework for international sales is no longer restricted to traditional sources controlled by the state, such as national legislation and international conventions, but also provides for norms that are recognised as authoritative sources of obligation by those who treat them as binding and, therefore, as autonomous law. ${ }^{77}$ The normative quality of these rules is derived from the fact that they are created through consultation with market players who participate in the law-making process. Standard form contracts of trade organisations are based on practices and usages of the particular trade, while standard and model contracts drafted by business organisations such as the ICC provide for a wider audience and seek to facilitate international trade by levelling the playing field and preventing a stronger party from imposing its terms onto a weaker party. ${ }^{78}$

The reality is that the legal framework for international trade is formulated by a variety of sources which consist of state and non-state norms. When it comes to recognising and enforcing non-state rules, it is essentially arbitral tribunals that keep the framework in place.

76 See Berman 2007 S Cal L Rev 1157-1158, 1174-1179; Smits 2015 https://papers.ssrn.com/sol3/Delivery.cfm?abstractid=2566149 4-5; Dalhuisen Transnational Law 32.

77 Berman 2007 S Cal L Rev 1157-1158, 1177-1178. Also see Goode 1997 Int'l Comp LQ 10.

78 Maurer 2012 https://papers.ssrn.com/sol3/papers.cfm?abstract_id=2179584 7-11. 


\section{An effective framework for international sales law}

\subsection{What and who determines the framework?}

What is an effective and realistic legal framework for international contracts of sale, and who is to determine what that framework should be?

As the law is shaped by political or economic considerations, it is no surprise that the supporters of universalism base their arguments on economic efficiency and the reduction of transaction costs. However, uniform law will never produce absolute uniformity or predictability. It is impossible to reach agreement on all the aspects of an international contract as the range of the matters that are to be regulated is too vast and constantly changing due to the dynamic nature of the international commercial environment. In the end, it is not the form (hard or soft) or level (national, international or supranational) per se of law that determines its relevance, value or success, but economic and market forces. Also, its effectiveness is not determined by whether it is produced by the state or not. Effective law is law that is capable of serving the needs of its users, and its effectiveness should therefore be measured by its economic value for its users and its ability to facilitate economic exchange..$^{79}$ As one scholar puts it, "its acceptance, perceived utility, and frequent use by those with economic influence in the relevant market for the law" will determine its efficiency, and therefore its success. ${ }^{80}$ The usefulness and commercial suitability of a law would firstly depend on whether it is an efficient and practical instrument for commercial traders and secondly on whether the courts can interpret the law consistently. ${ }^{81}$

This means that, if an effective regulatory framework is to be created, its users must be the main drivers of the process and not government officials, diplomats and legal scholars, as is normally the case with unification efforts. ${ }^{82}$ Commercial parties, attorneys, courts and arbitral tribunals that have to work with the law are better suited to this task. In the case of the CISG, the primary target audience was commercial traders, but the process of creating the law was left to government officials and state representatives. That might explain why the Convention is widely adopted by states, ${ }^{83}$ but also why business-to-business contracts often

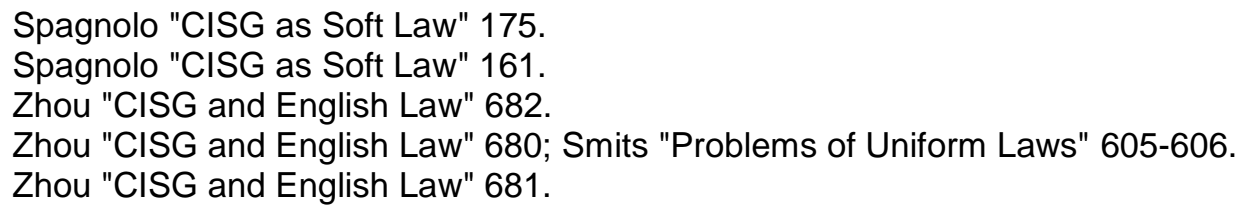


exclude the CISG in favour of domestic law or modify its provisions through party agreement.

Standard form contracts of trade associations that regulate the trade in international commodities, such as the Grain and Feed Trade Association (GAFTA), the Federation of Oils, Seeds, and Fats Association (FOSFA), the Refined Sugar Association (RSA), and international corporations such as Shell and British Petroleum all expressly exclude the Convention in favour of English law. ${ }^{84}$ Obviously there is a specific reason why these organisations elect to do so, and also why they prefer to make use of national law to regulate their contracts. These organisations are important market players and naturally legal certainty is an important consideration for them when it comes to a choice of law. They regard the inherently fragmentary and incomplete nature of the CISG as being economically inefficient. $^{85}$ Furthermore, ambiguous terms in the CISG are to be interpreted without clear guidance on the interpretation methodology. ${ }^{86}$ English law is often preferred as the choice of law for international contracts due to its completeness, legal certainty, and the dominant role that it played in regulating international trade during the eighteenth and early nineteenth centuries. The fact that English commercial law was largely shaped and influenced by merchants and their commercial needs is another reason why it is such a popular choice of law. ${ }^{87}$

Market forces in the form of network effects can, furthermore, elevate soft law from a mere contractual choice to a standard reference in contracts that regulate their particular trades. Incoterms and the Uniform Customs and Practice for Documentary Credits (UCP) are good examples here. ${ }^{88}$

\subsection{A pluralist approach}

In isolation, both sovereignist territorialism and universalist harmonisation cannot provide an effective legal framework for international sales. ${ }^{89}$ To recognise what is already happening in practice, the mechanisms, institutions and practices of international trade should make provision for plural voices and norms. ${ }^{90}$ As people are part of various communities such

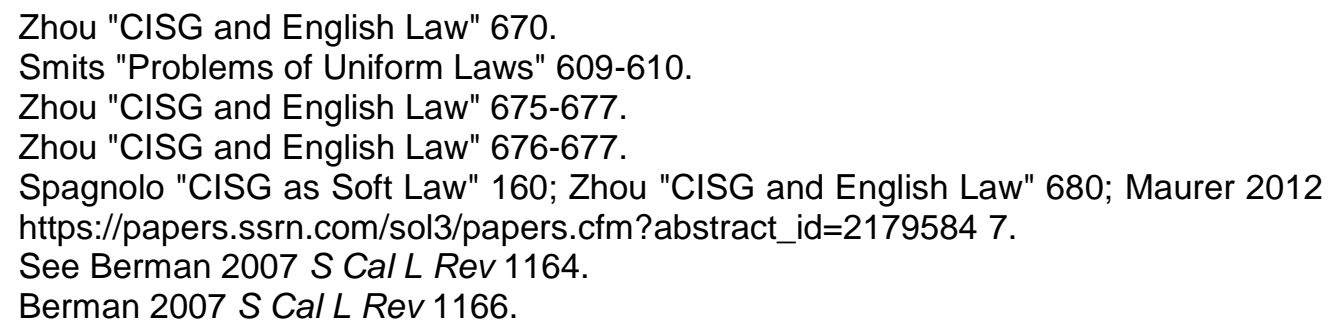


as a state legal order but at the same time also members of trade associations or other economic communities the law is shaped by a variety of communities (including the state) and a single transaction can be regulated by different legal norms.

Global legal pluralism allows for different law-making spaces, namely state and non-state law, but at the same time also for different types of law to function in tandem, whether they are national and supra-national rules, substantive rules or conflict-of-law rules. ${ }^{91}$ Pluralism, furthermore, recognises the importance of party autonomy and provides parties with the freedom to contract out of or deviate from uniform law when needed and to choose a national law or any other form of private regulation to govern their contract.

Legal pluralism and jurisdictional competition are definite forces within the international sales law paradigm of the twenty-first century. This should not be a cause for concern. ${ }^{92}$ Although the state's law-making role has been supplemented by other rule-making authorities, it should be emphasised that traditional law-making will not disappear and always remain an important part of any legal framework, especially insofar as mandatory substantive rules are concerned. The CISG, as an international sales law convention, will therefore still play an important role, and the number of contracting states will continue to rise. However, the primary role of the CISG is no longer only to facilitate international trade by means of a uniform sales law but it will increasingly become a model for harmonising national sales laws. National legislatures are already using the CISG as a model for revising their contract and sales laws. ${ }^{93}$ As a result, national sales laws will over time become more uniform, and this process constitutes a natural form of harmonisation. Moreover, where countries in an economic or geographical region are all Contracting States to the Convention, the CISG would automatically function as the regional sales law of the region.

Global legal pluralism ${ }^{94}$ would certainly receive its fair share of criticism from both universalists and territorialists alike on account of its lack of

91 Berman 2007 S Cal L Rev 1777 -1178.

92 Berman 2016 Unif $L$ Rev 13.

93 Schwenzer 2016 Unif L Rev 64-65. Examples are the 1988 Nordic Sale of Goods Act, 1999 Contract Law of the People's Republic of China and the 2002 German Law of Obligations.

94 For the history and development of legal pluralism, see Caliess and Buchmann 2016 https://papers.ssrn.com/sol3/papers.cfm?abstract_id=2717467 7-9; Maurer 2012 https://papers.ssrn.com/sol3/papers.cfm?abstract_id=2179584 12-13. 
legal certainty and predictability. However, the reality is that a pure approach is hardly sustainable as it is impossible to unify law to the extent that it will be absolutely complete and certain, or to adapt national laws so that they can address the special needs of international commerce in all of its facets due to the dynamic nature of international commerce. ${ }^{95}$

A pluralist framework is more efficient from a normative and practical perspective as it creates space and opportunity for multiple and sometimes even overlapping legal systems and approaches to operate together in an effort to create the best framework for a particular transaction. Parties will always remain free to keep to the CISG where it is applicable, and as more countries ratify the Convention and denounce the existing reservations, international sales law will become increasingly uniform. $^{96}$ However, sophisticated traders will continue to exclude the Convention or supplement it where necessary with national law or nonstate forms of regulation. This approach does not deny the role of universalism but gives legitimacy to the current fragmented landscape of international legal regulation.

In reaction to the Swiss Proposal for a new global contract law, support has been shown for the existing pluralist framework. The USA, for example, has rejected the Proposal and, in turn, proposed that the "modernization and harmonization of international contract law can best be achieved by continuing the existing structure".97 During the same session as that in which the Swiss Proposal was introduced, UNCITRAL also endorsed the PICC. ${ }^{98}$

\subsection{Managing pluralism}

A one-size-fits-all model is not feasible, as the efficiency of the applicable framework law would depend on the economic and market forces within which the transaction operated and, at the same time, also on the nature and needs of the particular transaction. This would boil down to a case-bycase approach. ${ }^{99}$ This might, in some instances, require supplementing a uniform law with a choice of law or a soft law instrument, whilst in other instances it might require that the applicable uniform law of the contract is to be excluded and replaced by what is most efficient for that transaction -

\footnotetext{
95 Berman 2007 S Cal L Rev 1164-1165. Also see Dalhuisen Transnational Law 30-33.

96 Castellani "CISG in Context" 684-685; Andersen "Reservations of the CISG" 7-11.

97 Dennis 2014 Unif L Rev 114-115.

98 Report of the United Nations Commission on International Trade Law, 45th Session UN Doc A/67/17 (2012) paras 137-140.

99 Berman 2007 S Cal L Rev 1236.
} 
even if that is a national law or a form of private rule-making such as a standard form contract.

The important lesson to be learnt from a pluralist approach is that there is no single or "correct" way to regulate an international sales transaction and that the choice of law will depend on the circumstances of each case. ${ }^{100}$ The ultimate challenge of a pluralist framework would be how to manage it, and how to mediate between the different law-making spaces, as all of them have equal normative authority. ${ }^{101}$

For one, the parties can organise their contractual relationships in such a manner as to ensure that disputes are not addressed in an ex post facto manner. They would need to act proactively and avoid disputes ex ante. ${ }^{102}$ They can, for example, ensure counter-performance in an informal manner by structuring performance and payment in instalments. Non-legal social structures and network relationships fulfil an important function in enforcing performance without the intervention of the state. Reliance on reputational remedies can be effectively used as a regulatory mechanism. Although this approach functions essentially on the basis of good faith and trust, parties often refrain from breaching contractual obligations due to the damage that a breach might bring to their international reputation. Expulsion from business networks has always been an effective sanction in international commerce. ${ }^{103}$ In the modern era, the use of information technology and the social media can enhance the effectiveness of this sanction, as it provides additional opportunities for naming and shaming. ${ }^{104}$ Pluralism can therefore be managed on an informal basis by the economic actors themselves without the intervention of official legal or state organs. ${ }^{105}$

\subsection{Pluralism in the context of the CISG}

Although the CISG is considered to be the most successful uniform law, it is not a complete law. It regulates a very specific range of matters, does not apply to all types of goods, and functions as a default law. That means that the Convention will never fully regulate all international contracts of sale, not even if all countries were to become Contracting States to the

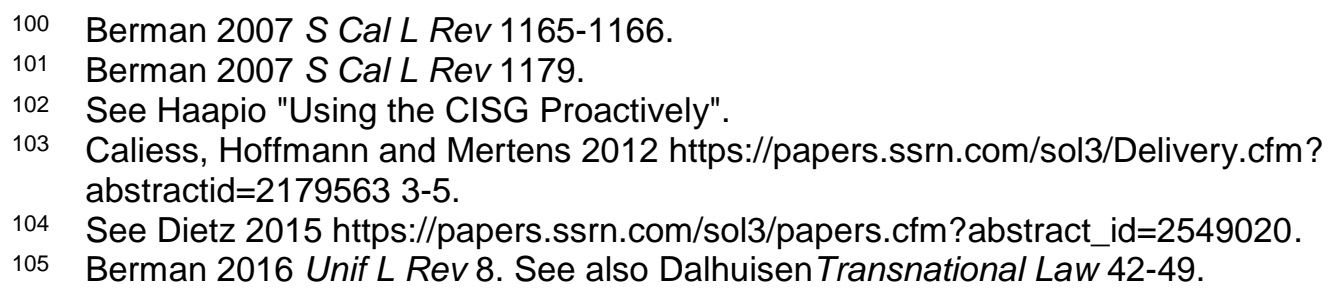


CISG, as it always has to be supplemented. Moreover, the essentially pluralist nature of the Convention is enforced by its interpretation provision, as courts and arbitral tribunals are directed to make use of "the law applicable by virtue of the rules of private international law" if no general principles are available. ${ }^{106} \mathrm{It}$ is therefore said that the Convention itself constitutes a hybrid or pluralist system. ${ }^{107}$

One scholar suggests a "CISG Plus" approach to fill the Convention's gaps. ${ }^{108}$ This approach would draw on existing hard and soft law instruments to "develop a widely accepted body of customary international law to overcome its limited scope". ${ }^{109}$ Support for such an approach is to be found in article 7 of the CISG, as this provision envisages the Convention as a living document that can develop through autonomous interpretation. Furthermore, as the CISG is a set of default rules, contractual parties are free to deviate from any of its provisions by virtue of article 6. This approach assigns an important role to the principle of party autonomy, which is one of the general principles on which the Convention is based. The International Chamber of Commerce's (ICC) Incoterms ${ }^{\circledR}$ rules are regularly used to displace the CISG's default rules on delivery and the passing of risk. These rules are codified by a private business organisation which acts as a non-state private rule-maker.

Scholars and practitioners, furthermore, support the interpretative and supplementary role of the PICC in filling the gaps in the CISG. ${ }^{110}$ On occasion the courts have made use of a pragmatic approach to fill the gaps in the Convention by means of the general principles of international trade as restated in the PICC. 111 There are, however, scholars who criticise such an approach. They argue that the general principles on which the Convention is based cannot be sourced from the PICC, as this instrument came into existence after the Convention had been adopted and could therefore not represent the principles on which the CISG was based. ${ }^{112}$ At its $45^{\text {th }}$ session, UNCITRAL explicitly stated that the PICC

\footnotetext{
106 Article 7(2) CISG.

107 Caliess and Buchmann 2016 https://papers.ssrn.com/sol3/papers.cfm?abstract_id =2717467 18-20; Berman 2016 Unif L Rev 4.

108 DiMatteo 2013 Vill L Rev 691, 719.

109 DiMatteo 2013 Vill L Rev 729.

110 Bonell "Towards a Legislative Codification" 235; Brödermann "Practice of Excluding" 246; Dennis 2014 Unif L Rev 151.

111 Belgium Supreme Court 2009 http://cisgw3.law.pace.edu/cases/090619b1.html; Netherlands Arbitration Institute 2002 http://cisgw3.law.pace.edu/ cases/021015n1.html.

112 DiMatteo 2013 Vill L Rev 712-713; Bridge 2013 Vill L Rev 489. Contra Michaels 2014 Unif L Rev 665-666.
} 
should not be construed as stating the general principles on which the Convention is based. ${ }^{113}$ However, in its endorsement of the 2010 PICC, UNCITRAL stated that the Principles of International Commercial Contracts and the CISG could have a complementary relationship and that the PICC could be used to interpret and supplement the Convention. ${ }^{114}$ This would not mean that, in the absence of any statement of the general principles on which the CISG is based, the PICC would provide a codification of those principles, but because they codify the principles of international trade in general they support the international character of the Convention and also include the principles reflected in the Convention. To that extent, the PICC could function as a new lex mercatoria. The courts are also increasingly making use of the PICC as so-called "background law" to develop and interpret national and international law in general. ${ }^{115}$

Furthermore, the PICC can supplement the CISG's provisions as "the law applicable by virtue of the rules of private international law". As different international legal orders, hard and soft, can supplement one another in a pluralist framework, the PICC can fulfil the role of a neutral opt-in supplementary law. However, this approach would not only depend the adoption of the CISG by states that have not yet opted to do so, but also on contractual parties choosing the PICC as the supplementary law of the contract. That would, in turn, depend on the willingness of courts to recognise the PICC as a law of choice. National courts are generally reluctant to recognise that a contract may be governed by general principles of law, and not only by state law. The 2015 Hague Principles on Choice of Law in International Commercial Contracts, which were recently adopted by the Hague Conference on Private International Law, (the Hague Principles) might trigger welcome change. ${ }^{116}$ The Hague Principles make provision that the parties to a contract can choose to have their contract governed by rules of law, and not only by state law. Arbitrators have recognised this practice for a long time already. ${ }^{117}$

113 Report of the United Nations Commission on International Trade Law, 46 $6^{\text {th }}$ Session UN Doc A/68/17 (2013) para 253.

114 Report of the United Nations Commission on International Trade Law, 45 $5^{\text {th }}$ Session UN Doc A/67/17 (2012) paras 137-140.

115 Michaels 2014 Unif $L$ Rev 658-659.

116 These Principles were endorsed by UNCITRAL at its $48^{\text {th }}$ session. Report of the United Nations Commission on International Trade Law, 48th Session UN Doc A/70/17 (2015).

117 Michaels 2014 Unif L Rev 664. Also see art 28 of the UNCITRAL Model Law on International Commercial Arbitration (1985, as amended in 2006), which makes provision that a dispute can be resolved with reference to rules of law. 


\section{Conclusion}

Traditionally, the diversity in national legal systems was addressed by unified law. To reduce transaction costs and uncertainty, universalists seek to erase normative differences in pursuit of a so-called world or global law. However, there is reason to question the desirability and feasibility of universalism just as one would do with territorial sovereignism. Uniform law is not always the ideal framework, as it often underestimates the strength of emotional ties to local or other communities and smothers the innovation and competition that can be brought about by diversity. Because differences in laws are the by-products of different histories, philosophies and worldviews, uniformity is often difficult to achieve. The discussion has also shown that uniformity is more apparent than real, as it is primarily based on compromises. Moreover, it can sometimes amount to a step backwards in that it codifies natural homogeneities but does not keep up with modern developments. ${ }^{118}$

In the end, what is efficient law should be determined by economic forces and not by the form of the law itself, whether that is hard, soft, uniform, diverse, state or non-state law. In practice, a diversity of sources already regulates international contracts in a collaborative effort. This can be by way of a combination of hard and soft law options, for example the CISG supplemented by the PICC or Incoterms, or even by national law.

There is no need to revise the CISG or to formulate a new global contract law, as the existing sales law convention already represents a hybrid or pluralist model. In a hybrid system uniform law will not disappear but it will no longer function as the ultimate framework for international sales law. The CISG's role will increasingly move from that of being a unified global law to that of shaping commercial culture and the "legal consciousness" of commercial parties, as it continues to influence and develop international instruments as well as national laws and their interpretation. ${ }^{119}$

The current hybrid approach is to be supported. Global legal pluralism is a middle ground, ${ }^{120}$ and although it is sometimes messy it is the reality of the present world order, where a single commercial actor is regulated by multiple law makers and norm setters. ${ }^{121}$ As for managing a pluralist

\footnotetext{
118 Berman 2007 S Cal L Rev 1189-1191.

119 Berman 2016 Unif $L$ Rev 9-13; Caliess and Buchmann 2016 https://papers.ssrn.com/sol3/papers.cfm?abstract_id=2717467 15 . Also see Schwenzer 2016 Unif L Rev 64-65.

120 Berman 2007 S Cal L Rev 1195.

121 Berman 2007 S Cal L Rev 1235-1236.
} 
approach, this has to be done on a case-by-case basis. Party autonomy would be a key ingredient, as contractual parties should choose a legal framework that is economically efficient for their specific transaction. In order to optimally utilise party autonomy as a tool to manage pluralism, choice-of-law rules should provide parties the opportunity to choose both state and non-state rules to govern their contracts. Parties can also avoid disputes by arranging their contractual relationships carefully and using the power of social and relational sanctions. Courts and arbitral tribunals can play an important role in mediating between the different norms and acting pragmatically when filling gaps in laws through a "nuanced interpretation that seeks to knit together local and international norms into a new combination". ${ }^{122}$

In the twenty-first century it can no longer be argued that uniform or global law is the most efficient legal framework for international contracts of sale. ${ }^{123}$ There is no one-size-fits-all approach but different forms of regulation have to function together to supplement and complement one another. The principles of party autonomy and contractual freedom, together with trade usage, national law and uniform law and other international instruments of harmonisation act in tandem to provide a framework that offers a relative degree of legal certainty and predictability, but at the same time also much-needed flexibility.

A pluralist framework should be viewed as an opportunity rather than a problem. ${ }^{124}$ It can become a durable framework for international sales law if it is effectively managed by its users, the courts and arbitral tribunals. From a South African perspective, an autonomy-based approach would find support in our constitutional values of freedom and equality, and would contribute to developing the law of contract, and more specifically the law relating to international transactions.

\section{Bibliography}

\section{Literature}

Andersen "Reservations of the CISG"

Andersen CB "Reservations of the CISG: Regional Trends and Developments" in Schwenzer I and Spagnolo I (eds) Globalisation versus Regionalization (Eleven International The Hague 2013) 1-12

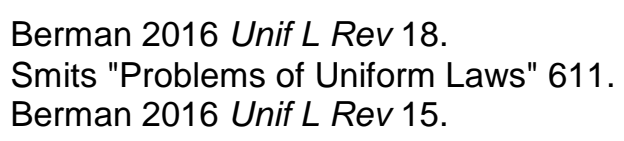


Berman 2007 S Cal L Rev

Berman PS "Global Legal Pluralism" 2007 S Cal L Rev 1155-1237

Berman 2016 Unif L Rev

Berman PS "The Inevitable Legal Pluralism within Universal Harmonization Regimes: The Case of the CISG" 2016 Unif L Rev 1-18

Bonell 2000 Unif $L$ Rev

Bonell MJ "Do We Need a Global Commercial Code?" 2000 Unif $L$ Rev 469-481

Bonell "Towards a Legislative Codification"

Bonell MJ "Towards a Legislative Codification of the Unidroit Principles" in UNCITRAL Modern Law for Global Commerce: Proceedings of the Congress of the United Nations Commission on International Trade Law Held on the Occasion of the Fortieth Session of the Commission (9-12 July 2007 Vienna) 230-239

Bonell 2008 Am J Comp L

Bonell MJ "The CISG, European Contract Law and the Development of a World Contract Law" 2008 Am J Comp L 1-28

Bridge 2013 Vill L Rev

Bridge MJ "An Overview of the CISG and an Introduction to the Debate About the Future Convention" 2013 Vill L Rev 487-490

Brödermann "Practice of Excluding"

Brödermann EJ "The Practice of Excluding the United Nations Sales Convention: Time for Change?" in UNCITRAL Modern Law for Global Commerce: Proceedings of the Congress of the United Nations Commission on International Trade Law Held on the Occasion of the Fortieth Session of the Commission (9-12 July 2007 Vienna) 245-249

Castellani "CISG in Context"

Castellani LG "The CISG in Context of Complementary Texts" in DiMatteo LA (ed) International Sales Law: A Global Challenge (CUP New York 2014) 683-693

Cuniberti 2014 Nw J Int'l L \& Bus

Cuniberti G "The International Market for Contracts: The Most Attractive Contract Laws" 2014 Nw J Int'I L \& Bus 455-516 
Dalhuisen Transnational Law

Dalhuisen J Dalhuisen on Transnational Comparative, Commercial, Financial and Trade Law Vol 1 Introduction - The New Lex Mercatoria and its Sources (Hart Oxford) 2010

Dennis 2014 Unif $L$ Rev

Dennis MJ "Modernizing and Harmonizing International Contract Law: The CISG and the PICC Continue to Provide the Best Way Forward" 2014 Unif $L \operatorname{Rev} 114-151$

DiMatteo 2013 Vill L Rev

DiMatteo LA "CISG as Basis of a Comprehensive International Sales Law" 2013 Vill L Rev 691-721

DiMatteo and Janssen "Interpretive Methodologies"

DiMatteo LA and Janssen A "Interpretive Methodologies in the Interpretation of the CISG" in DiMatteo LA (ed) International Sales Law: A Global Challenge (CUP New York 2014) 79-101

Farnsworth 1996 Can Bus LJ

Farnsworth EA "Unification and Harmonization of Private Law" 1996 Can Bus LJ 48-62

Farnsworth 2003 Unif $L$ Rev

Farnsworth EA "Modernization and Harmonization of Contract Law: An American Perspective" 2003 Unif $L$ Rev 97-106

Fassberg 2004 Chi J Int'l L

Fassberg CW "Lex Mercatoria Hoist with Its Own Petard?" 2004 Chi J Int'I L67-82

Gabriel "Choice of Law"

Gabriel HD "Choice of Law, Contract Terms and Uniform Law in Practice" in UNCITRAL Modern Law for Global Commerce Proceedings of the Congress of the United Nations Commission on International Trade Law Held on the Occasion of the Fortieth Session of the Commission (9-12 July 2007 Vienna) 224-229

Gabriel 2013 Vill L Rev

Gabriel HD "UNIDROIT Principles as a Source for Global Sales Law" 2013 Vill L Rev 661-680 
Goode 1997 Int'l Comp LQ

Goode RM "Usage and Its Reception in Transnational Commercial Law" 1997 Int'l Comp LQ 1-36

Haapio "Using the CISG Proactively"

Haapio H "Using the CISG Proactively" in DiMatteo LA (ed) International Sales Law: A Global Challenge (CUP New York 2014) 704-723

Hermann "Law, International Commerce and the Formulating Agencies" Herrmann G "Law, International Commerce and the Formulating Agencies - The Future of Harmonisation and Formulating Agencies: The Role of UNCITRAL" Unpublished paper presented at the Centre of Commercial Law Studies Schmitthoff Symposium 2000: Law and Trade in the 21st Century (1-3 June 2000 London)

Hermann "Towards a Global Commercial Code"

Hermann G "Towards a Global Commercial Code for Borderless Commerce: Global Commerce Needs Global Law" Unpublished paper presented at Pennsylvania State University Dickinson School of Law $10^{\text {th }}$ Biennial Meeting of the International Academy of Commercial and Consumer Law (9-13 August 2000 Carlisle, Pennsylvania)

Kadens 2012 Texas $L R$

Kadens E "The Myth of the Customary Law Merchant" 2012 Texas LR 1153-1206

Lando 2003 Unif L Rev

Lando O "Principles of European Contract Law and UNIDROIT Principles: Moving from Harmonisation to Unification?" 2003 Unif L Rev 123-133

Loken 2013 Vill L Rev

Loken K "A New Global Initiative on Contract Law in UNCITRAL: Right Project, Right Forum?" 2013 Vill L Rev 509-520

Michaels 2014 Unif $L$ Rev

Michaels RC "The UNIDROIT Principles as Global Background Law" 2014 Unif L Rev 643-668

Michaels 2016 German LJ

Michaels R "Does Brexit Spell the Death of Transnational Law?" 2016 German LJ (Brexit Suppl) 51-61 
Moser "Choice of Law in Practice"

Moser LGM "Choice of Law in Practice - A Global Empirical Survey" Unpublished paper delivered at University of Basel, UNCITRAL and the Swiss Association for International Law 35 Years CISG and Beyond (2930 January 2015 Basel)

Perales Vascasillas 2013 Vill $L$ Rev

Perales Vascasillas P "Applicable Law, the CISG, and the Future Convention on International Commercial Contracts" 2013 Vill L Rev 733759

Rabel 1935 RabelsZ

Rabel E "Der Entwurf eines einheitlichen Kaufgesetzes" 1935 RabelsZ 1104

Schmitthoff "Law of International Trade"

Schmitthoff CM "The Law of International Trade" in Cheng C-J (ed) Clive M Schmitthoff's Select Essays on International Trade Law (Martinus Nijhoff Dordrecht 1988) 219-230

Schmitthoff "Codification of the Law of International Trade"

Schmitthoff CM "Codification of the Law of International Trade" in Cheng C-J (ed) Clive M Schmitthoff's Select Essays on International Trade Law (Martinus Nijhoff Dordrecht 1988) 243-252

Schroeter "Empirical Evidence"

Schroeter UG "Empirical Evidence of Courts' and Counsels' Approach to the CISG (with Some Remarks on Professional Liability)" in DiMatteo LA (ed) International Sales Law: A Global Challenge (CUP New York 2014) 649-668

Schwenzer 2013 Vill L Rev

Schwenzer I "Who Needs a Uniform Contract Law, and Why?" 2013 Vill L Rev 723-732

Schwenzer "Divergent Interpretations"

Schwenzer I "Divergent Interpretations: Reasons and Solutions" in DiMatteo LA (ed) International Sales Law: A Global Challenge (CUP New York 2014) 102-119

Schwenzer 2016 Unif $L$ Rev

Schwenzer I "Global Unification of Contract Law" 2016 Unif L Rev 60-74 
Smits "Economic Arguments"

Smits JM "Economic Arguments in the Harmonization Debate: The Practical Importance of Harmonization of Commercial Contract Law" in UNCITRAL Modern Law for Global Commerce: Proceedings of the Congress of the United Nations Commission on International Trade Law held on the Occasion of the Fortieth Session of the Commission (9-12 July 2007 Vienna) 46-52

Smits "Problems of Uniform Laws"

Smits JM "Problems of Uniform Laws" in DiMatteo LA (ed) International Sales Law: A Global Challenge (CUP New York 2014) 605-611

Sono 1984 Int'l Law

Sono K "UNCITRAL and the Vienna Sales Convention" 1984 Int'l Law 715

Spagnolo "CISG as Soft Law"

Spagnolo L "The CISG as Soft Law and Choice of Law: Gōjū Ryū?" in DiMatteo LA (ed) International Sales Law: A Global Challenge (CUP New York 2014) 154-175

Veneziano 2013 Vill L Rev

Veneziano A "The Soft Law Approach to Unification of International Commercial Contract Law: Future Perspectives in Light of UNIDROIT'S Experience" 2013 Vill L Rev 521-528

Wagner "Transaction Costs"

Wagner G "Transaction Costs, Choice of Law and Uniform Contract Law" in UNCITRAL Modern Law for Global Commerc:e Proceedings of the Congress of the United Nations Commission on International Trade Law held on the Occasion of the Fortieth Session of the Commission (9-12 July 2007 Vienna) 39-45

Wagner "Costs of Legal Uncertainty"

Wagner $\mathrm{H}$ "Costs of Legal Uncertainty: Is Harmonization of Law a Good Solution?" in UNCITRAL Modern Law for Global Commerce: Proceedings of the Congress of the United Nations Commission on International Trade Law held on the Occasion of the Fortieth Session of the Commission (9-12 July 2007 Vienna) 53-60

Winship 1988 Cornell Int'l LJ

Winship P "Private International Law and the UN Sales Convention" 1988 Cornell Int'I LJ 487-533 
Zhou "CISG and English Law"

Zhou Q "The CISG and English Law: An Unfair Competition" in DiMatteo LA (ed) International Sales Law: A Global Challenge (CUP New York 2014) 669-682

\section{Legislation}

American Uniform Commercial Code, 1952

Contract Law of the People's Republic of China, 1999

German Law of Obligations, 2002

Nordic Sale of Goods Act, 1988

\section{International instruments}

Current Trends in the Field of International Sale of Goods Law UN Doc A/CN 9/849 (2015)

Geneva Convention on Agency in the International Sale of Goods (1983)

International Chamber of Commerce Incoterms ICC Pub 715E (2010)

International Chamber of Commerce Uniform Customs and Practice for Documentary Credits ICC Pub 600 LE (2007)

Hague Principles on Choice of Law in International Commercial Contracts (2015)

Note by the Secretariat of the International Institute for the Unification of Private Law (UNIDROIT): Progressive Codification of the Law of International Trade UN Doc A/CN 9/L.19 (1970)

Possible Future Work in the Area of International Contract Law: Proposal by Switzerland on Possible Future Work by UNCITRAL in the Area of International Contract Law UN Doc A/CN 9/758 (2012)

Report of the United Nations Commission on International Trade Law, $45^{\text {th }}$ Session UN Doc A/67/17 (2012)

Report of the United Nations Commission on International Trade Law, $46^{\text {th }}$ Session UN Doc A/68/17 (2013) 
Report of the United Nations Commission on International Trade Law, $48^{\text {th }}$ Session UN Doc A/70/17 (2015)

UNCITRAL Model Law on International Commercial Arbitration (1985, as amended in 2006)

UNIDROIT Principles of International Commercial Contracts (2010)

Uniform Act on General Commercial Law (2010)

Uniform Law on the Formation of Contracts for the International Sale of Goods (1964)

Uniform Law on the International Sale of Goods (1964)

Uniform Rules on Contract Clauses for an Agreed Sum Due upon Failure of Performance (1983)

United Nations Convention on Contracts for the International Sale of Goods (1980)

United Nations Convention on the Limitation Period in the International Sale of Goods (1974)

United Nations Convention on the Use of Electronic Communications in International Contracts (2005)

\section{Internet sources}

Belgium Supreme Court 2009 http://cisgw3.law.pace.edu/cases/ 090619b1.html

Belgium Supreme Court 2009 Scafom International BV v Lorraine Tubes SAS http://cisgw3.law.pace.edu/cases/090619b1.html accessed 1 August 2016

Caliess and Buchmann 2016 https://papers.ssrn.com/sol3/papers.cfm?ab stract_id $=2717467$

Caliess G-P and Buchmann I 2016 Global Commercial Law between Unity, Pluralism, and Competition: The Case of the CISG - ZenTra Working Papers in Transnational Studies No 63/2016 1-20 
https://papers.ssrn.com/sol3/papers.cfm?abstract_id=2717467 accessed 1 August 2016

Caliess, Hoffmann and Mertens 2012 https://papers.ssrn.com/sol3/De livery.cfm?abstractid $=2179563$

Caliess G-P, Hoffmann H and Mertens JM 2012 The Transnationalisation of Commercial Law - ZenTra Working Papers in Transnational Studies No 04/2012 1-19 https://papers.ssrn.com/sol3/Delivery.cfm?abstractid= 2179563 accessed 1 August 2016

Dietz 2015 https://papers.ssrn.com/sol3/papers.cfm?abstract_id=2549020 Dietz T 2015 Transnational Business and Relational Contracting 2.0 ZenTra Working Papers in Transnational Studies No 45/2015 1-22 https://papers.ssrn.com/sol3/papers.cfm?abstract_id=2549020 accessed 1 August 2016

Maurer 2012 https://papers.ssrn.com/sol3/papers.cfm?abstract_id $=2179584$

Maurer A 2012 The Creation of Transnational Law: Participatory Legitimacy of Privately Created Norms - ZenTra Working Papers in Transnational Studies No 03/2012 1-15 https://papers.ssrn.com/sol3/ papers.cfm?abstract_id=2179584 accessed 1 August 2016

Netherlands Arbitration Institute 2002 http://cisgw3.law.pace.edu/cases/ 021015n1.html

Netherlands Arbitration Institute Case No 2319, 2002, Condensate Crude Oil Mix Case http://cisgw3.law.pace.edu/cases/021015n1.html accessed 1 August 2016

Smits 2013 https://papers.ssrn.com/sol3/papers.cfm?abstract_id=2197468 Smits JM 2013 Problems of Uniform Sales Law: Why the CISG May Not Promote International Trade - Maastricht European Private Law Institute Working Paper No 2013/1 1-11 https://papers.ssrn.com/sol3/papers.cfm? abstract_id=2197468 accessed 1 August 2016 
Smits 2015 https://papers.ssrn.com/sol3/Delivery.cfm?abstractid=2566149 Smits JM 2015 The Future of Contract Law in Europe - Maastricht European Private Law Institute Working Paper No 2015/2 1-16 https://papers.ssrn.com/sol3/Delivery.cfm?abstractid=2566149 accessed 1 August 2016

UNCITRAL 1980 http://www.uncitral.org/uncitral/en/uncitral_texts/sale_ goods/1980CISG_status_chronological.html

$\begin{array}{lllll}\text { UNCITRAL } & 1980 & \text { CISG } & \text { Status } & \text { Chronological }\end{array}$ http://www.uncitral.org/uncitral/en/uncitral_texts/sale_goods/1980CISG_st atus_chronological.html accessed 1 August 2016

\section{List of Abbreviations}

\begin{tabular}{|c|c|}
\hline Am J Comp L & American Journal of Comparative Law \\
\hline Can Bus LJ & Canadian Business Law Journal \\
\hline Chi J Int'I L & Chicago Journal of International Law \\
\hline CESL & Common European Sales Law \\
\hline CISG & $\begin{array}{l}\text { United Nations Convention on Contracts for } \\
\text { the International Sale of Goods (1980) }\end{array}$ \\
\hline Cornell Int'I LJ & Cornell International Law Journal \\
\hline DCFR & Draft Common Frame of Reference \\
\hline EU & European Union \\
\hline FOSFA & $\begin{array}{l}\text { The Federation of Oils, Seeds, and Fats } \\
\text { Association }\end{array}$ \\
\hline GAFTA & The Grain and Feed Trade Association \\
\hline German LJ & German Law Journal \\
\hline Hague Principles & $\begin{array}{l}\text { Hague Principles on Choice of Law in } \\
\text { International Commercial Contracts }\end{array}$ \\
\hline ICC & International Chamber of Commerce \\
\hline Int'I Comp LQ & International Comparative Law Quarterly \\
\hline Int'I Law & The International Lawyer \\
\hline Nw J Int'l L \& Bus & $\begin{array}{l}\text { Northwestern Journal of International Law } \\
\text { and Business }\end{array}$ \\
\hline OHADA & $\begin{array}{l}\text { Organisation for the Harmonisation of } \\
\text { Business Laws in Africa }\end{array}$ \\
\hline PACL & Principles of Asian Contract Law \\
\hline PECL & Principles of European Contract Law \\
\hline
\end{tabular}


PICC

PLDC

RabelsZ

S Cal L Rev

RSA

Texas LR

UNCITRAL

UNIDROIT

Unif L Rev

UCC

UCP

ULF

ULIS

UN

USA

Vill L Rev
Principles of International Commercial Contracts

Principles of Latin American Contract Law

Rabels Zeitschrift für ausländisches und internationales Privatrecht

Southern California Law Review

The Refine Sugar Association

Texas Law Review

United Nations Commission on International Trade Law

Institute for the Harmonisation of Private

Law

Uniform Law Review

American Uniform Commercial Code

Uniform Customs and Practice for Documentary Credits

Uniform Law on the Formation of Contracts for the International Sale of Goods

Uniform Law on the International Sale of Goods

United Nations

United States of America

Villanova Law Review 